\title{
NASIONALISME DAN GERAKAN MULIH NJOWO, 1947 DAN 1954
}

\author{
Susanti \\ Arsip Nasional Republik Indonesia \\ Alamat korespondensi: susanti@gmail.com \\ Diterima/ Received: 20 Juli 2016 ; Disetujui/ Accepted: 1 Agustus 2016

\begin{abstract}
This article concerns on nationalism that was within repatrian Suriname in 1947 and 1954. It was known as the "Mulih Njowo" Movement. The movement arouse due to various factors experienced by the contracted Javanese laborers in Suriname. One of those factors was nationalism. The existence of Javanese in Suriname was triggered by the policy of the Dutch Government, and as a process of diaspora. They migrated to a new place (Suriname), and interacted with the people there. However, they still had bonding emotion with Java. The movemnt's participants felt close with their homeland, local traditions and also the official authorities in the region. It is found that Mulih Njowo Movement in 1947 and 1954 motivated by several factors; disappointment and discrimination from the Dutch Government; a hard life in Suriname; social status; unfair treatment by plantation overseer; stronger sense of nationalism; sense of belonging to Java Island which raises a yearning for the homeland, and a desire to build Indonesia as a new independent country.
\end{abstract}

Keywords: nationalism, movement, diaspora.

\begin{abstract}
Abstrak
Artikel ini berusah mengungkap adanya nasionalisme dalam repatrian Suriname pada 1947 dan 1954. Hal ini dikenal sebagai Gerakan "Mulih Njowo". Gerakan ini membangkitkan masyarakat Jawa di Suriname untuk kembali ke Jawa karena berbagai faktor yang dialami. Mayoritas mereka adalah buruh. Salah satu faktor yang melatarbelakangi gerakan ini adalah adanya nasionalisme. Keberadaan Jawa di Suriname dipicu oleh kebijakan Pemerintah Belanda, dan sebagai proses diaspora. Mereka bermigrasi ke tempat baru (Suriname), dan berinteraksi dengan orang-orang di sana. Namun, mereka masih memiliki ikatan emosi dengan Java. Mereka yang telah berpartisipasi dalam Gerakan Mulih Njowo pada 1947 dan 1954 merasa dekat dengan tanah air mereka, tradisi lokal, dan juga otoritas resmi yang terdapat di Jawa. Hal ini ditemukan bahwa Gerakan Mulih Njowo pada 1947 dan 1954 didorong oleh beberapa faktor; kekecewaan dan diskriminasi dari Pemerintah Belanda; kehidupan yang keras di Suriname; status sosial; perlakuan yang tidak adil oleh pengawas perkebunan; perasaan nasionalisme yang kuat; rasa rindu mendalam ke Pulau Jawa dan khusushnya tanah air, dan keinginan untuk membangun Indonesia sebagai negara baru yang merdeka.
\end{abstract}

Kata kunci: nasionalisme; Gerakan Mulih Njowo; diaspora 


\section{PENDAHULUAN}

Belanda merupakan salah satu dari Negara Eropa yang banyak melakukan ekspansi ke beberapa Negara yang kemudian menjajahnya, diantaranya adalah Suriname dan Indonesia. Suriname merupakan sebuah negara yang terletak di tepi pantai Lautan Atlantik di Benua Amerika bagian selatan dengan luas kurang lebih $163.265 \mathrm{~km}^{2}$. Negara ini menjadi wilayah yang diperebutkan antara Pemerintah Belanda dengan Inggris (Toon, 2004: 52). Namun pada akhirnya Suriname berada di bawah kekuasaan Belanda. Pada sekitar 1800 Suriname merupakan sebuah wilayah yang subur dan kaya akan sumber daya alam. Namun ada satu masalah besar di Suriname yang kemudian melatarbelakangi pengiriman penduduk dari berbagai daerah koloni Belanda, yaitu kurangnya sumber daya manusia secara kuantitas dan kualitas (Wawancara dengan Sarmoeji pada 17 November 2008).

Hal yang demikian itu tentu menjadi sebuah masalah besar yang harus dipecahkan oleh Pemerintah Belanda yang berkuasa di Suriname. Apalagi setelah pihak swasta Belanda yang berinvestasi di Suriname dipandang gagal dalam mendatangkan pekerja dari luar Suriname seperti pulau jajahan Spanyol, Portugis, dan Tiongkok (Ismael, 1955: 27), karena para pekerja dari pulaupulau jajahan tersebut ternyata bukan orang-orang yang tepat untuk bertani dan berkebun. Oleh sebab itu, Pemerintah Kolonial Belanda kemudian mendatangkan budak dari Afrika. Seiring dengan berjalannya waktu, perbudakan dihapuskan dari tanah Suriname. Dengan adanya kebijakan penghapusan perbudakan, Pemerintah Belanda mulai mendatangkan pekerja kontrak dari negara lain seperti India, Cina, dan Hindia Belanda, khususnya Jawa.

Pulau Jawa sebagai salah satu wilayah jajahan Belanda pada awal abad XIX, memiliki kondisi alam yang hampir sama dengan Suriname, yaitu seperti tanah yang sangat subur, sehingga dapat dikatakan segala yang ditanam dengan mudah akan tumbuh (Wawancara dengan Sarmoeji pada 17 November 2008). Namun demikian pada sisi yang lain, Pulau Jawa juga memiliki jumlah penduduk yang padat dan ratarata hidup dalam kemiskinan. Sisi lain dari kultur tipologi umum yang dimiliki penduduk Pulau Jawa khususnya yang berasal dari lapisan bawah adalah dikenal sebagai orang yang rajin dan mahir dalam bercocok tanam. Kondisi di Jawa tersebut melatarbelakangi kebijakan politik Pemerintah Kolonial Belanda untuk mengirimkan orang-orang Jawa sebagai pekerja kontrak ke Suriname. Bagi orang Jawa sendiri, alasan yang melatarbelakangi mereka menjadi pekerja di Suriname berbedabeda. Terdapat orang Jawa yang terpaksa pergi ke Suriname karena kondisi yang sulit di Jawa dan ingin memperbaiki kehidupan. Terdapat pula yang berangkat ke Suriname karena ditipu atau diculik.

Pada 1890 Pemerintah Kolonial Belanda di Suriname mulai mendatangkan buruh dari Pulau Jawa dengan didasarkan pada pasal 70 Keputusan Kerajaan Belanda tertanggal 22 Maret 1872 No. 27. Isi dari Keputusan Kerajaan Belanda tersebut mengatur tentang perjanjian kontrak kerja orang Jawa selama lima tahun, dan setelah itu mereka memiliki hak untuk bebas kembali ke tanah air, kecuali bagi mereka yang telah menerima premi (ANRI, Arsip Algemeene Secretarie Templaar No. 1031). Mereka dipekerjakan di berbagai perkebunan kopi, cokelat, dan tebu serta di pertambangan bauxit milik Alumunium Company of America (ALCOA) dengan ikatan kontrak selama lima tahun. Dengan demikian status sosial mereka pada umumnya hanya sebagai tenaga kerja atau buruh yang dipekerjakan di berbagai sektor baik pertanian, perkebunan, maupun pertambangan. Setelah empat tahun mengerjakan perkebunan di Suriname, hasil kerja orang Jawa tersebut dianggap baik. Hasil kerja Suku Jawa tersebut memuaskan Pemerintah Belanda, sehingga akhirnya pekerja-pekerja dari Pulau Jawa mulai didatangkan ke Suriname secara rutin sejak 
1890 hingga 1939. Pengiriman orang Jawa ke Suriname berlangsung selama 49 tahun dengan jumlah total 32.956 orang (Ismael, 1955: 30). ${ }^{1}$

Dalam kehidupan sehari-hari di Suriname, orang Jawa (Indonesia). ${ }^{1}$ berbaur dengan orangorang dari negara lain. Selain orang Jawa, juga terdapat orang dari bangsa Eropa, Creol, India, Tionghoa, dan lain-lain (Ismael, 1955: 19). Terdapat kecenderungan masing-masing etnis dan bangsa tinggal menetap secara berkelompok, sehingga di Suriname terbentuk perkampungan Indonesia (lebih dikenal dengan sebutan Jawa), perkampungan Cina, perkampungan Creol, perkampungan India, dan lain-lain. Pada awalnya kehidupan di Suriname bukan merupakan hal yang mudah. Ada persaingan antara suku bangsa yang berbeda tersebut, terutama dalam masalah politik. Posisi dalam bidang politik saat itu dipegang oleh suku bangsa mayoritas, yaitu Creol. Bangsa India sebagai etnis kedua terbesar di Suriname, sedangkan Suku Jawa merupakan etnis ketiga terbesar yang ada di Suriname. Dalam pergaulan dengan bangsa-bangsa lain tersebut, tidak ada kendala yang berarti bagi orang-orang dari Suku Jawa, mereka hidup bersama dengan rukun dan damai (Wawancara dengan Sastro Amidjan 10 Februari 2009 (khasanah sejarah lisan ANRI)). Hal ini terjadi karena sejak awal pemerintah kolonial Belanda di Suriname telah membuat kebijakan politik penempatan mereka (suku Creol, India, Cina, dan Jawa) secara berkelompok. Demikian juga halnya dengan suku Jawa di Suriname, mereka tinggal mengelompok, tetapi juga dapat bersosialisasi secara baik dengan suku dan bangsa lain yang ada di Suriname.

Namun demikian sebagai migran, orang Jawa di Suriname tetap memiliki ikatan emosional dengan daerah asalnya, sehingga keinginan untuk kembali selalu muncul. Oleh karena itu ketika perjanjian dalam kontrak yang menyebutkan, bahwa para pekerja kontrak memiliki hak untuk kembali ke tanah asalnya tanpa biaya setelah kontrak kerja selesai, tidak ditepati. Mereka mengalami kesulitan untuk bisa kembali ke tanah asal dan berusaha dengan berbagai cara untuk dapat kembali. Terlebih setelah Indonesia merdeka, kemauan untuk kembali ke tanah air semakin kuat, maka kemudian terjadilah gelombang kembalinya migran Jawa di Suriname ke tanah air Indonesia atau yang dikenal dengan nama gerakan Mulih Njowo. Permasalahan yang menarik untuk dikaji dari fenomena tersebut, antara lain:

1. Bagaimana dan mengapa para migran Jawa di Suriname termotivasi untuk melakukan gerakan Mulih Njowo pada 1947 dan 1954 secara kolektif?

2. Bagaimana proses gerakan Mulih Njowo itu berlangsung, siapa atau kelompok mana yang berperan serta bagaimana cara yang ditempuh?

\section{METODE}

Penelitian ini menggunakan metode sejarah, yaitu proses menguji, menganalisis, dan mengonstruksi secara kritis sumber-sumber sejarah yang merupakan rekaman dan peninggalan peristiwa masa lalu, yang kemudian dituangkan dalam penulisan sejarah secara sistematis, logis, dan kronologis (Gottschalk, 1986: 32). Dalam metode sejarah pada prinsipnya terdapat empat tahapan kegiatan, yaitu heuristik atau pengumpulan sumber sejarah, kritik atau pengujian sumber sejarah, interpretasi atau sintesis, dan historiografi atau penulisan sejarah.

Tahap pertama, yaitu heuristik atau pengumpulan sumber sejarah merupakan langkah awal yang sangat penting dalam penulisan sejarah. Penulisan sejarah hanya dapat dilakukan kalau ada sumbernya atau ada dokumen sebagai bukti dari adanya peristiwa masa lampau. Tanpa sumber sejarah, sebuah karya sejarah tidak akan bisa ditulis. Sumber sejarah yang digunakan dalam penelitian ini berupa sumber primer dan sumber sekunder, baik tertulis maupun tidak tertulis terutama hasil wawancara terhadap pelaku sejarah yang terlibat atau menyaksikan dengan pandangan 
mata secara langsung terhadap peristiwa yang dikaji.

Sumber primer tertulis yang digunakan dalam penelitian ini berupa arsip atau dokumen tertulis yang tersimpan di Arsip Nasional Republik Indonesia (ANRI) di Jakarta. Dari lembaga arsip ini dapat ditemukan rekaman sezaman seperti surat keputusan, maklumat, pernyataan, dan berbagai dokumen pemerintah yang lain, baik dokumen yang ditulis oleh Pemerintah Belanda (Arsip Algemeene Secretarie Templar), maupun oleh Pemerintah Indonesia (Arsip Kepolisian Negara), serta tulisan yang dibuat oleh orang suku Jawa di Suriname (Arsip Kabinet Presiden). Sementara itu, sumber primer lisan berupa hasil wawancara dengan para pelaku dan saksi sejarah (wawancara dengan orang Jawa dari Suriname tentang Penelusuran Jejak Masyarakat Suriname di Indonesia) yang terlibat langsung atau menyaksikan langsung peristiwa sejarah yang dikaji dalam tulisan ini. Penyusunan tulisan ini juga memanfaatkan sumber yang terdapat pada Berita ANTARA dan beberapa surat kabar dari Perpustakaan Nasional seperti Kedaulatan Rakyat, Haluan, Harian Umum Nasional, dan beberapa buku tentang Suriname lainnya. Sumber-sumber sekunder yang digunakan berupa buku ataupun literatur yang berkaitan dengan peristiwa gerakan Mulih Njowo. Dari sumber-sumber ini ditemukan informasi yang berkaitan dengan permasalahan yang dikaji dalam penelitian ini (Gottschalk, 1986: 32; Kartodirdjo, 1982: 96-122).

Tahap kedua, adalah kritik sumber yang merupakan tahap pengujian terhadap sumbersumber sejarah yang telah diperoleh pada tahapan heuristik. Kritik sumber dilakukan untuk menilai otentisitas dan kredibilitas sumber sejarah yang diperoleh. Penilaian atau pengujian terhadap sumber-sumber sejarah yang telah dikumpulkan dilakukan melalui kritik eksteren dan kritik interen. Kritik eksteren digunakan untuk menguji otentisitas atau keaslian sumber sejarah yang telah ditemukan. Hal yang sangat penting di sini adalah apakah sumber itu asli atau palsu. Sementara itu, kritik interen dilakukan untuk mengetahui, apakah sumber tersebut memberikan informasi sesuai dengan yang dibutuhkan, isinya sesuai dengan yang sedang dikaji, memberikan arti pada dokumen, membandingkan antara sumber-sumber yang dihasilkan, sumber yang satu dengan yang lain ada kesesuaian ataukah tidak, dan mana yang lebih sesuai. Kritik sumber dalam penelitian ini dilakukan dengan membandingkan antara informasi yang telah diketahui sebelumnya melalui literatur yang ada dengan isi informasi yang terkandung di dalam arsip serta informasi yang diberikan oleh informan dari wawancara sejarah lisan. Selain itu, kesesuaian informasi dalam arsip juga ditemukan dalam berita beberapa surat kabar sezaman. Perbedaan yang ada hanya dalam jumlah/angka mengenai orang Jawa dari Suriname yang kembali ke Indonesia.

Tahap ketiga adalah melakukan interpretasi sumber yaitu menetapkan makna dan saling hubungan dari fakta-fakta yang diperoleh dari sumber sejarah yang telah ditemukan (Gottschalk, 1986: 17). Kegiatan ini secara sistematis juga mencakup kegiatan analisis dan sintesis antara satu fakta dengan fakta lain yang kemudian disusun secara kronologis sesuai dengan urutan waktu. Di samping itu tahap ini juga mencakup langkahlangkah untuk mengaitkan satu fakta sejarah dengan fakta sejarah yang lain dalam ikatan hubungan sebab-akibat atau kausalitas. Dengan cara demikian akan dapat dikontruksi cerita sejarah yang utuh dan bulat serta koheren. Penelitian ini dilakukan dengan menghubungkan antara informasi yang tertulis dalam beberapa dokumen pemerintah, informasi yang diperoleh dari wawancara sejarah lisan, informasi dari beberapa surat kabar serta informasi dari beberapa makalah yang dibuat sendiri oleh orang Jawa dari Suriname.

Langkah yang keempat adalah historiografi. Langkah ini merupakan langkah terakhir dari metode sejarah, yaitu melakukan kegiatan untuk 
menyusun fakta-fakta sejarah yang sudah dikumpulkan, dikritik, dan dianalisis dan disintesiskan untuk kemudian disusun menjadi sebuah cerita sejarah. Langkah ini merupakan tahap akhir dari suatu penelitian sejarah. Pada tahap penelitian ini, penulis akan menyajikan tulisan dalam bentuk cerita sejarah yang disusun secara kronologis, artinya sesuai dengan urutan waktu peristiwa (Gottschalk, 1986: 19). Dalam tahap historiografi, penulis berusaha menyusun cerita sejarah berdasarkan kronologi dan tematema tertentu menurut prinsip kebenaran dan objektivitas dalam sejarah agar penelitian ini dapat menghasilkan cerita sejarah yang dapat dipertanggungjawabkan secara ilmiah.

\section{MIGRASI ORANG JAWA KE SURINAME}

Gerakan Mulih Njowo yang dilakukan migran di Suriname pada 1947 dan 1954 tentu tidak bisa dipisahkan dari latar belakang kepergian mereka ke Suriname, dan kehidupan yang dijalani selama di Suriname, serta kondisi di Suriname dan Indonesia setelah menjadi negara merdeka. Sebagaimana diketahui, sebagian dari para pekerja suku Jawa yang berangkat ke Suriname bertujuan untuk memperbaiki nasib mereka yang pada umumnya hidup dalam garis kemiskinan di Pulau Jawa, dan mereka sudah mengetahui apa yang akan mereka kerjakan serta apa yang akan mereka dapatkan sebagai pekerja kontrak di Suriname (sesuai dengan informasi dari para werk/calo pencari tenaga kerja). Namun demikian, selain dengan cara dan mekanisme yang sesuai prosedur tersebut, dalam praktiknya ada juga beberapa dari orang Jawa yang dibohongi atau bahkan diculik, dan kemudian dikirimkan ke Suriname (Sarmoedjie, 2006: t.h.). Penculikan dilakukan dengan cara membohongi, bahwa ada anggota keluarga yang ingin menemuinya, namun kemudian ia dibius, dan ketika sadar, ia sudah berada di atas kapal yang membawa mereka ke Suriname.
Para werk menggunakan berbagai macam cara untuk dapat merekrut tenaga kerja dari suku Jawa, karena untuk setiap tenaga kerja yang diperoleh mereka mendapatkan upah sebesar 80 sen per hari. Cara-cara yang digunakan di antaranya adalah dengan menghembuskan isu bahwa mereka (para tenaga kerja Jawa) akan memperoleh upah sebesar 60 per hari. Upah itu lebih besar dua kali lipat dibandingkan dengan upah kerja di Jawa pada saat itu, yaitu sebesar 33 sen. Selain itu, mereka juga akan menerima seekor kerbau, alat-alat pertanian dan uang 100 sen setelah kontrak kerja selama lima tahun selesai (Ismael, 1955: 39). Isu-isu tersebut dihembuskan guna menarik orang Jawa yang pada saat itu hidup dalam kemiskinan untuk mendapatkan penghidupan yang lebih baik di Suriname. Gambaran tentang hal itu antara lain dapat dilihat pada gambar brosur yang ada di bawah ini. ${ }^{2}$

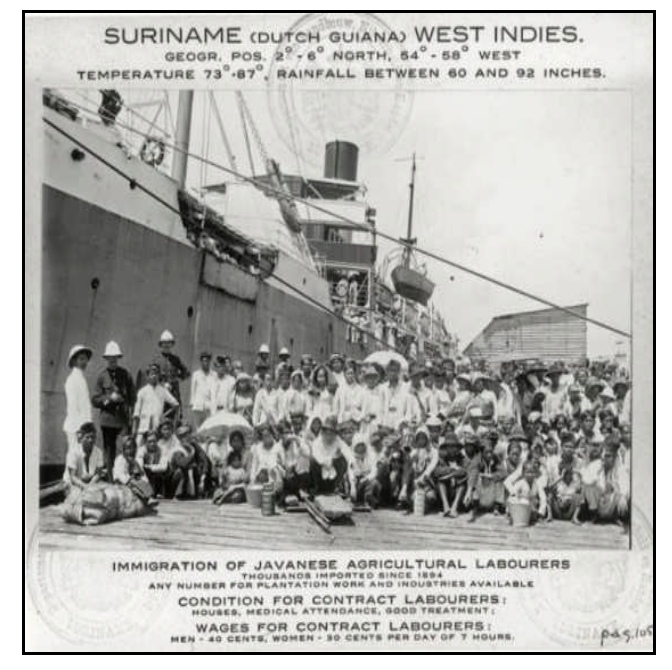

Gambar 1. Pekerja Perkebunan dari Jawa (www.javanenindiaspora.nl, 2012)

Isu yang dihembuskan werk berlainan dengan perjanjian kontrak yang sebenarnya. Hal ini baru diketahui oleh pekerja kontrak dari Jawa ketika mereka tiba di Suriname. Perjanjian kontrak baru dilakukan setelah mereka tiba di Suriname. Keberangkatan orang-orang suku Jawa ke Suriname berdasar pada perjanjian kontrak. Dalam 
perjanjian kontrak tersebut mereka dijadikan pekerja kontrak selama lima tahun di bawah Poenale Sanctie. ${ }^{4}$ Selama lima tahun tersebut setiap hari mereka harus bekerja selama tujuh jam di perkebunan, atau sepuluh jam di pabrik, dan untuk itu bagi pekerja laki-laki memperoleh upah sebanyak 40 sen sehari, sedangkan pekerja perempuan hanya memper-oleh 30 sen sehari. Selain hak atas upah kerja, dalam perjanjian kontrak tersebut juga dijanjikan bahwa setelah lima tahun bekerja baik di perkebunan maupun di pabrik di Suriname, mereka memiliki hak untuk dapat kembali ke Pulau Jawa tanpa dipungut biaya atau dengan kata lain secara cuma-cuma. Akan tetapi, bagi mereka yang belum ingin kembali ke Indonesia boleh memperpanjang masa kontraknya satu tahun lagi atau bekerja terus di Suriname sebagai buruh bebas (Hardjo, 1989: 11). Bagi mereka yang ingin tetap di Suriname (bersedia melepaskan haknya untuk pulang ke Pulau Jawa) akan mendapat uang sebesar 100 gulden Suriname untuk dipergunakan sebagai biaya hidup di Suriname. Selain itu, mereka juga akan diberikan peralatan yang dibutuhkan dalam pertanian dan tanah seluas dua hektar (Wawancara dengan Teguh Paimin Sastroprawiro 11 Desember 2008 (Khasanah Sejarah Lisan ANRI).

\section{GERAKAN MULIH NJOWO}

Pada kenyataannya tidak semua perjanjian dalam peraturan kontrak antara Pemerintah Belanda dengan orang suku Jawa dipenuhi oleh Pemerintah Belanda, terutama perjanjian tentang hak untuk dapat kembali ke Pulau Jawa setelah bekerja selama lima tahun secara cuma-cuma. Setelah mereka bekerja selama lima tahun, mereka tidak secara otomatis dapat pulang ke Jawa dengan gratis. Pada saat itu orang suku Jawa di Suriname hidup dalam kondisi yang memprihatinkan. Kondisi yang memprihatinkan ini disebabkan oleh keadaan mereka hidup dalam ketertinggalan. Ketertinggalan tersebut salah satunya disebabkan oleh meletusnya Perang Dunia I pada 1914-1918 yang berakibat perekonomian dunia berantakan (Hardjo, 1989: 12). Perkebunan di Suriname juga tidak terlepas dari dampak Perang Dunia I. Beberapa perusahaan perkebunan tersebut akhirnya tutup, sehingga mereka yang bekerja di perkebunan menjadi pengangguran.

Kondisi tersebut akhirnya membuat para pekerja khususnya orang Jawa di Suriname terpaksa melepaskan haknya untuk dapat kembali ke tanah air yaitu Pulau Jawa. Dengan melepaskan hak tersebut, mereka dapat menerima dari pemerintah sejenis ganti rugi berupa uang tunai, yang umumnya disebut uang kapal atau premi sebesar Sf.100,- (seratus gulden Suriname) (Hardjo, 1989: 13). Istilah yang digunakan oleh mereka dengan menerima uang seratus gulden Suriname itu adalah Ngedunke Jangkar (menurunkan jangkar/sauh) yang artinya mereka telah mengikat dirinya pada tanah Suriname. Hal ini menyebabkan tidak semua orang dari suku Jawa yang pergi ke Suriname dapat kembali lagi ke Pulau Jawa. Kondisi di atas, menjadi alasan bagi orang Jawa di Suriname untuk melakukan suatu pergerakan yang dapat membawa mereka kembali ke tanah asal mereka yaitu Pulau Jawa. Faktorfaktor kekecewaan akibat dari janji-janji yang tidak ditepati di atas, ikut mendorong keinginan orang suku Jawa kembali ke tanah airnya.

Di samping faktor janji-janji yang tidak ditepati oleh Pemerintah Kolonial Belanda, ada beberapa hal lagi yang membuat orang Jawa pada akhirnya melakukan Gerakan Mulih Njowo. Para pekerja kontrak dari Jawa di Suriname kerap mendapat perlakuan yang sewenang-wenang dari opseter-opseter ${ }^{5}$ perkebunan. Kondisi lain yang menimbulkan keinginan yang kuat dari suku Jawa untuk dapat kembali ke tanah air adalah posisi mereka dalam hubungan sosial dengan suku bangsa lain di Suriname. Suku Creol sebagai suku yang dominan menganggap orang dari India dan Jawa yang pada saat itu datang sebagai indentured laborers, yaitu orang yang rendah. Hal ini tampak 
jelas terutama di dalam perkebunan yang menempatkan suku Creol adalah pemimpin/memiliki posisi yang lebih tinggi, sedangkan para indentured laborers adalah orang yang lebih rendah/berada di bawahnya.

Perlakuan buruk terhadap para indentured laborers bukan suatu hal yang tidak biasa. Mereka kerap dianggap rendah dan mendapat perlakuan yang kejam. Kondisi tersebut terutama dialami oleh suku Jawa karena tidak ada peraturan yang melindungi mereka. Walaupun tidak ada diskriminasi secara tertulis, namun terkadang mereka merasa menjadi warga yang dianaktirikan oleh Belanda. Pemerintah Belanda dianggap lebih mendahulukan kepentingan bangsa lain dibandingkan kepentingan dari suku Jawa. Kondisi-kondisi tersebut tentu saja mengecewakan para pekerja kontrak dari Jawa di Suriname karena mereka merasa telah ikut membantu Pemerintah Belanda dalam membangun Suriname. Rasa kecewa akan perlakuan tidak baik dari suku Creol terhadap suku Jawa sejak tahun 1890 hingga tahun 1946 serta rasa diskriminasi dari pemerintah Belanda, ikut mendorong mereka untuk pulang ke tanah air.

Berita proklamasi kemerdekaan Indonesia pada 17 Agustus 1945 juga ikut menjadi salah satu faktor pendorong para pekerja kontrak Jawa untuk kembali ke Indonesia pada 1947 dan 1954. Mereka sebagai bagian dari Indonesia, ingin ikut merasakan sebagai orang yang bebas dan merdeka. Berita tentang kemerdekaan Indonesia, ikut memperkuat rasa nasionalisme mereka. Selain ingin ikut merasakan menjadi orang yang merdeka, orang Jawa di Suriname juga ingin ikut membantu/berbuat dalam membangun Indonesia. Sebagai negara yang baru merdeka, Indonesia tentu membutuhkan bantuan tenaga terutama dari mereka yang telah memiliki keahlian di berbagai bidang.

Keterikatan para pekerja kontrak Jawa terhadap Pulau Jawa, juga menjadi salah satu faktor yang mendorong keinginan untuk dapat pulang ke tanah air. Perasaan menjadi bagian dari keluarga besar Jawa, dapat tetap tumbuh di dalam hati orang-orang suku Jawa di Suriname, meskipun mereka telah menempati Suriname selama beberapa waktu. Perasaan tersebut telah menimbulkan persatuan di antara mereka. Walaupun mereka bersosialisasi juga dengan orang dari bangsa lain, namun rasa persatuan mereka justru semakin tumbuh. Hal ini disebabkan oleh beberapa faktor, yaitu: asal-usul yang sama, perasaan senasib, persamaan adat-istiadat, persamaan bahasa, agama, persamaan orientasi politik selama tinggal menetap di Suriname (Ismael, 1955: 73).

Dalam salah satu berita yang disiarkan oleh Kantor Berita ANTARA pada 8 Desember 1947 dikemukakan, bahwa setelah mereka (repatrian Suriname) tiba kembali di tanah air, mereka ingin mencurahkan tenaga untuk turut berjuang memperkuat kedudukan Negara Republik Indonesia (ANRI, Arsip Berita ANTARA, 1947). Masih dalam salah satu berita dari ANTARA pada 13 Desember 1947, diberitakan bahwa rombongan orang-orang Indonesia dari Suriname yang datang kembali ke Tanah Air pada 25 Oktober 1947, datang menghadap Presiden Soekarno untuk menyampaikan bantuan berupa pakaian dan obatobatan agar diberikan kepada orang yang membutuhkannya (ANRI, Arsip Berita ANTARA, 1947). Ini merupakan salah satu bentuk dari keinginan mereka untuk ikut berbuat sesuatu untuk membantu Indonesia tanah airnya. Semangat nasionalisme ini juga tampak dari semboyan-semboyan yang mereka buat seperti: saenak-enak'e di negoro wong, sih enak di negara dewe; daripada hujan emas di negara orang, lebih baik hujan batu di negara sendiri; turu nang isor batang pisang dilakoni (Wawancara dengan Antonius Dasimin Senawi 3 Desember 2008 (Khasanah Sejarah Lisan ANRI). Makna yang terkandung dalam semboyan-semboyan tersebut adalah bahwa orang Jawa di Suriname merasa lebih senang berada di negara sendiri yaitu Indonesia. Walaupun kehidupan di Suriname mungkin lebih baik, dan di kehidupan di Indonesia 
mungkin lebih buruk, tetap lebih baik berada di Indonesia. Bagaimanapun kehidupan di Indonesia akan mereka terima.

Pada kenyataannya bukan hal yang mudah untuk dapat kembali ke tanah air. Hal ini terbukti dengan pernah adanya semacam demonstrasi yang dilakukan suku Jawa Suriname untuk dapat kembali ke pulau Jawa (Indonesia). Demonstrasi ini dilakukan oleh para pekerja dari Jawa di Suriname sebelum kepulangan mereka pada 1947. Dari salah satu arsip berupa surat yang dibuat oleh Kepala Kepolisian Daerah Istimewa Yogyakarta dapat dilihat betapa kuat keinginan dari orang Jawa yang ada di Suriname untuk dapat kembali ke Indonesia. Setelah tersiar berita proklamasi kemerdekaan Indonesia yang dibacakan oleh Soekarno timbul perasaan nasionalisme yang kuat, sehingga mendorong keinginan orang Jawa di Suriname untuk dapat kembali ke Indonesia. Setelah dilakukan demonstrasi yang dipimpin oleh Sudijono, maka kurang lebih 782 orang Jawa di Suriname dapat mewujudkan mimpinya untuk kembali ke Indonesia.

Cara yang dilakukan oleh 782 orang Jawa di Suriname itu adalah dengan mengumpulkan sejumlah uang untuk menyewa kapal yang akan membawa mereka kembali ke Indonesia sebagaimana disarankan oleh Sudijono. Kapal yang digunakan untuk kembali ke Indonesia pada 1947 adalah kapal Tabian. Adapun biaya yang dibutuhkan ntuk menyewa kapal tersebut adalah sebesar Sf. 280.000 (ANRI, Arsip Algemeene Secretarie Templar No. 1031), dan biaya tersebut harus ditanggung oleh para imigran yang menjadi penumpangnya. Setiap imigran dikenakan biaya Sf. 300 (ANRI, Arsip Algemeene Secretarie Templaar No. 1031). Di dalam kapal itu, Pemerintah Belanda menyediakan tenaga medis seorang dokter dengan dua orang asistennya guna melayani kebutuhan medis para imigran selama dalam perjalanan. Kapal M.S. Tabian tiba di pelabuhan Paramaribo pada 23 September 1947 dan berangkat ke Indonesia pada hari yang sama pukul 12.00 .

Melihat kondisi demikian, Pemerintah Kolonial Belanda tidak tinggal diam. Dari arsip Berita Antara diketahui bahwa ada semacam upaya pemerintah Belanda untuk mempertahankan orang-orang Jawa yang ada di Suriname. Cara yang dilakukan adalah dengan mempermudah orangorang Jawa di Suriname menjadi warga negara Belanda, yaitu cukup dengan membubuhkan cap jempol saja. Hal ini dilakukan Belanda karena kekhawatiran mereka akan kehilangan tenaga kerja yang rajin dan murah (ANRI, Arsip Berita Antara, 1954). Status otonomi yang diperoleh Suriname pada 1950, tidak serta merta membuat para pekerja Jawa di Suriname ingin menjadi warga negara Belanda. Berdasar hasil penghitungan formulir pernyataan tentang status kewarganegaraan yang dipilih dan yang disebarkan oleh Pemerintah Kolonial Belanda, ternyata kurang lebih $75 \%$ bangsa Indonesia berikut keturunannya yang ada di Suriname menolak kewarganegaraan Belanda. Mereka tetap ingin menjadi warga Negara Indonesia (Hardjo, 1989: 23). Kondisi ini yang kemudian mendorong kemunculan berbagai organisasi dengan tujuan utamanya kembali ke tanah air Indonesia.

Untuk dapat menampung dan merealisasikan keinginan orang-orang suku Jawa pulang ke Tanah Air, telah dilakukan upaya berupa pendirian partai dengan tujuan utamanya adalah Pulang ke Tanah Air. Pendirian partai dengan tujuan tersebut, mulai dilakukan pada 1946 dan pada umumnya partai yang memiliki tujuan untuk Pulang ke Tanah Air mendapat dukungan banyak dari orang-orang suku Jawa di Suriname.

Di antara partai atau perkumpulan politik yang didirikan, ada dua perkumpulan politik yang memegang peranan penting yaitu Persatuan Bangsa Indonesia Suriname (PBIS.) dan Kaum Tani Persatuan Indonesia (KTPI). Kedua organisasi tersebut secara umum bertujuan untuk kebaikan suku Jawa Suriname. Hanya saja PBIS 
lebih berorientasi kepada perbaikan kehidupan suku Jawa di Suriname, sedangkan KTPI. lebih berorientasi kepada pulang ke Tanah Air. Besarnya keinginan untuk kembali ke pulau Jawa menjadi latar belakang dari terbentuknya Yayasan Tanah Air. Pada 15 Oktober 1951, Yayasan Tanah Air (YTA.) berdiri. Dalam pasal 2 Anggaran Dasar yayasan tersebut, disebutkan bahwa yayasan ini didirikan dengan tujuan untuk mencari kemungkinan bagi bangsa Indonesia di Suriname khususnya, dan di luar negeri umumnya untuk kembali ke tanah air Indonesia. Dalam hal ini, diusahakan kesempatan untuk menjalankan perusahaan pertanian, perikanan, perdagangan, perindustrian dan usaha-usaha lain yang dapat dilakukannya untuk ikut serta membangun nusa dan bangsa. Melihat tujuan dari YTA, dengan cepat yayasan tersebut memperoleh anggota orang suku Jawa yang ada di Suriname. Organisasi YTA kemudian menamakan gerakan untuk kembali ke Indonesia dengan sebutan Gerakan Mulih Njowo.

Upaya selanjutnya yang dilakukan oleh pengurus YTA adalah dengan menghubungi perwakilan R.I. di Suriname dan menyampaikan akan adanya keinginan dari orang Indonesia (suku Jawa) untuk dapat kembali ke Jawa/Indonesia. Hal ini juga dilakukan oleh organisasi lain dengan tujuan yang sama. Akhirnya dibentuk rombongan delegasi yang terdiri dari delapan orang sebagai wakil organisasi masing-masing untuk berangkat dengan pesawat terbang ke Jakarta dan menghadap pemerintah RI. Tujuan dari rombongan delegasi ke Indonesia adalah untuk membicarakan soal rakyat Indonesia di Suriname berhubung dengan keinginannya pulang ke Indonesia dengan Pemerintah Republik Indonesia. Rombongan tersebut berangkat atas biaya pemerintah R.I. pada 24 Desember 1951.

Dari rangkaian perjalanan yang ditempuh oleh rombongan delegasi, dapat dikatakan bahwa pemerintah Indonesia menerima dengan baik maksud dan kedatangan dari rombongan delegasi. Artinya pemerintah Indonesia juga menyambut baik keinginan orang Jawa di Suriname untuk kembali ke Indonesia. Sambutan dan kesediaan para pejabat pemerintah Indonesia untuk menemui rombongan delegasi, sebagai salah satu bukti. Setelah beberapa orang delegasi mengunjungi beberapa tempat di Indonesia dengan mempertimbangkan jumlah penduduk dan lahan yang tersedia, maka kunjungan yang berlangsung lebih dari satu bulan tersebut, sementara memperkirakan bahwa mereka yang akan kembali ke Tanah Air akan ditempatkan di Lampung (Hardjo, 1989: 27-9). Sepulangnya rombongan delegasi itu dari Indonesia, mereka melaporkan kepada anggota dari organisasi masing-masing mengenai keadaan di Indonesia dan kemungkinan mereka untuk dapat tinggal di Indonesia. Selain itu anggota delegasi juga melaporkan hasil kunjungannya ke Indonesia kepada perwakilan Indonesia di Suriname, yaitu Komisaris Negara Republik Indonesia yang berada di Paramaribo, Suriname.

\section{DINAMIKA MIGRAN SURINAME DALAM GERAKAN MULIH NJOWO}

Gerakan Mulih Njowo bukan berarti pulang ke Jawa, karena pada kenyataannya mereka tidak dapat pulang ke pulau Jawa. Pada saat itu, pulau Jawa sudah padat penduduknya. Oleh sebab itu, rencananya semula mereka ditempatkan di daerah Lampung. Pada perkembangan kemudian, dari hasil pertemuan delegasi dengan Jawatan Transmigrasi Pusat di Indonesia, diketahui bahwa rombongan repatrian dari Suriname tidak dapat ditempatkan di Lampung, tetapi mereka akan ditempatkan di Sumatera Barat. Suku Jawa Suriname yang ingin ikut dalam rombongan kembali ke Indonesia di bawah pimpinan YTA diwajibkan membayar sejumlah uang sebagai biaya transportasi ke Indonesia. Adapun biayanya adalah sebagai berikut:

Dewasa per orang : : Sf. 375

Anak 10 tahun keatas : Sf. 375

Anak usia 1-9 tahun : Sf. 187,50 
Anak $<1$ tahun : tidak membayar (Hardjo, 1989: 36).

Biaya tersebut harus dibayar oleh repatrian Suriname yang akan ikut menjadi penumpang di Kapal Langkoeas dengan catatan minimal yang ikut adalah 1000 orang. Pada akhirnya, para pekerja dari Jawa berangkat dari pelabuhan Paramaribo menuju Indonesia pada 4 Januari 1954 dengan menggunakan Kapal Langkoeas.

Akhirnya kapal Langkoeas merapat di Pelabuhan Teluk Bayur, Padang Sumatera Barat pada 3 Februari 1954. Kedatangan repatrian Suriname di Padang disambut langsung oleh Menteri Sosial R.P. Suroso (Harian Umum Nasional, 10 Februari 1954). Selain itu hadir pula Mulyohardjo selaku Gubernur Sumatera Barat dan Drs. J. Ismail dari Kementerian Luar Negeri RI serta S.M. Hardjo selaku Ketua YTA yang telah berangkat terlebih dahulu. Kedatangan repatrian Suriname ke Padang diterima dengan baik oleh Pemerintah Indonesia. Pada malam harinya rombongan repatrian Suriname tersebut disambut oleh panitia khusus di Gedung Kesenian Kota Padang. Dalam artikel yang diberitakan oleh Harian Umum Nasional sebagai hasil wawancara harian tersebut dengan R.P. Suroso, dinyatakan bahwa Pemerintah Indonesia menerima mereka dengan tangan terbuka dan merasa gembira sekali bahwa mereka tidak lupa kepada tanah airnya. Ia juga menyatakan bahwa rombongan repatrian itu akan ditempatkan di Sukamenanti, salah satu daerah di Pasaman yang merupakan daerah yang tanahnya subur dan mudah mendapatkan air. Di samping itu, hutan di Sukamenanti hanya semaksemak saja, sehingga mudah untuk dibuka. Selain itu dikatakan pula bahwa tiap keluarga akan memperoleh tanah seluas lima hektar. Namun pada kenyataanya, fakta yang ada berbeda dari yang dikatakan oleh R.P. Soeroso. S.M. Hardjo selaku Ketua Y.T.A. dalam bukunya mengatakan bahwa tanah yang sedianya dijanjikan oleh Pemerintah Indonesia seluas 2.500 ha untuk setiap keluarga, ternyata hanya diberikan 1.500 ha (Hardjo, 1989: 44).

Setelah tiba di Padang, rombongan repatrian tersebut dibagi menjadi tiga kelompok. Kelompok pertama ke Sukamenanti pada 5 Februari 1954 (dua hari setelah mereka tiba di Padang). Rombongan kedua berangkat ke Sukamenanti pada 8 Februari 1954, dan rombongan ketiga berangkat tiga hari kemudian, yaitu pada 11 Februari 1954. Setelah tiba di Sukamenanti, tepatnya di daerah Kenegarian Air Gadang Kabupaten Pasaman mereka tinggal di bedeng sementara yang telah disiapkan oleh pemerintah Indonesia. Bedeng berukuran $4 \times 4$ meter tersebut terbuat dari seng dengan beratapkan rumbia (Wawancara dengan Antonius Dasimin Senawi pada 3 Desember 2008 (Khasanah Sejarah Lisan ANRI). Pada 12 Februari 1954 semua repatrian yang terbagi dalam tiga rombongan itu telah berada di Kenegarian Air Gadang. Kedatangan mereka ini disambut secara adat oleh wali negari beserta ninik-mamak, cerdikpandai, alim-ulama, para sesepuh dan pemuka masyarakat setempat. Dalam acara tersebut, hadir pula Kepala Jawatan Transmigrasi Provinsi dan para pejabat kabupaten dan kecamatan (Hardjo, 1989: 42).

Dari uraian di atas, dapat dikatakan bahwa pada saat itu semua pihak baik dari pihak pemerintah Indonesia maupun dari pihak masyarakat Sumatera Barat, menyambut dengan baik kedatangan para repatrian dari Suriname tersebut. Dengan kedatangan mereka, diharapkan dapat membawa kemajuan di wilayah Sumatera Barat yang pada saat itu masih banyak daerah yang berupa hutan belantara. Selain penghargaan mereka terhadap repatrian Suriname karena telah dapat mempertahankan nasionalismenya di negara yang jauh, mereka juga mengharapkan dampak yang positif atas kehadiran para repatrian di Sumatera Barat. Sebagaimana dikatakan oleh R.P. Soeroso dalam Harian Umum Nasional bahwa mengingat adanya bermacam-macam keahlian 
pada orang-orang itu, maka dapatlah diharapkan terbentuknya satu desa atau kampung yang moderen di Sukamenanti.

Dengan bermacam-macam tenaga yang diperlukan oleh satu desa yang moderen terdapat di kalangan mereka dan dengan usaha gotongroyong orang-orang yang datang dari Suriname itu akan dapatlah menciptakan satu penghidupan yang baik di tempat tinggal mereka yang baru. Apalagi pada umumnya mereka mempunyai syarat-syarat yang cukup sebagai bekal guna menjalankan usahanya. Umpamanya mereka sudah mempunyai macam-macam kendaraan bermotor yang diperlukan yaitu jeep, truk, dan traktor pembuka tanah yang akan datang kemudian (Harian Umum Nasional, 10 Februari 1954). Rombongan repatrian dari Suriname ini dapat dikatakan sebagai imigran yang mandiri, karena selain membiayai sendiri transportasi mereka menuju Indonesia, mereka juga menjual harta benda mereka di Suriname dan sebagian digunakan untuk membeli peralatan yang sekiranya dibutuhkan untuk membuka lahan di Indonesia. Pemerintah Indonesia hanya cukup menyediakan lahan untuk tempat tinggal dan lahan garapan sebagai mata pencaharian untuk kehidupan mereka di Indonesia.

\section{SIMPULAN}

Dari pembahasan tersebut dapat dibuat simpulan, bahwa gerakan Mulih Njowo yang berlangsung pada 1947 dan 1954 oleh repatrian dari Suriname, terjadi oleh karena dipengaruhi beberapa faktor dalam berbagai aspek. Secara sosial, mereka sebagai kelompok sosial lapisan bawah baik ketika di daerah asal di Jawa maupun di Suriname menghadapi tekanan sosial dari kelompok lain. Mereka merasa dipecundangi, diakali, dan disiasiakan, maka ketika mengetahui Indonesia telah merdeka, berkeinginan dan kemudian berjuang untuk kembali ke tanah air Indonesia. Secara ekonomi, repatrian dari Suriname mempunyai pengalaman empiris merasakan dieksploitasi oleh
Pemerintah kolonial Belanda terutama ketika hakhaknya sebagai pekerja seperti yang tertuang dalam perjanjian kontrak diingkari, tidak ditepati oleh pemerintah kolonial Belanda. Secara politik, kebijakan pemerintah kolonial Belanda yang dirasakan diskriminatif dan represif oleh repatrian dari Suriname, menimbulkan perasaan senasib sepenanggungan sebagai satu komunitas sosial suku bangsa. Oleh karena itu, ketika kemerdekaan Indonesia berhasil diraih, mereka merasa sebagai bagian dari bangsa Indonesia dan kemudian memiliki kecintaan yang luar biasa pada bangsa dan negaranya Indonesia. Dengan demikian, gerakan Mulih Njowo yang dilakukan migran di Suriname tersebut merupakan manifestasi dari adanya akumulasi persoalan yang dihadapi mereka selama menjalani kehidupan di Suriname dalam interaksi dan interelasinya dengan bangsa-bangsa lain. Juga tidak dapat dipisahkan dari tumbuh kembangnya nasionalisme di kalangan mereka.

\section{CATATAN}

${ }^{1}$ Pada kenyataannya, jumlah orang yang berangkat dari Jawa ke Suriname, tidak sama dengan jumlah orang yang bekerja di Suriname. Ada beberapa orang yang meninggal dalam perjalanan ke Suriname. Kondisi tersebut pernah terjadi pada 1894 (saat pemberangkatan gelombang kedua dari Jawa ke Suriname). Dari 584 orang yang berangkat dari Jawa, 64 orang di antaranya meninggal dunia dan sebanyak 85 orang dirawat di rumah sakit. Hal ini terjadi karena kapal tidak memenuhi syarat sebagai kapal angkut dan penumpang melebihi kapasitas muatan (Sarmoedjie, 2006: 1-2).

${ }^{2} \mathrm{Pada} 1890$ Indonesia belum terbentuk/belum merdeka, sehingga masih dikenal dengan namanama suku. Suku Jawa merupakan salah satu suku yang secara kuantitas dominan di Indonesia, sehingga tenaga kerja yang dikirim ke Suriname berasal dari suku Jawa.

${ }^{3}$ Gambar di atas merupakan semacam brosur yang disebarkan guna menarik minat orang Jawa untuk bekerja di Suriname sebagai tenaga kontrak. 
Gambar di atas diambil pada saat berada di Pelabuhan Paramaribo pada 1923. Dalam gambar tersebut, selain terdapat foto beberapa orang Jawa dengan latar belakang kapal yang digunakan untuk membawa mereka ke Suriname, juga dilengkapi dengan beberapa keterangan, baik keterangan berupa fasilitas dan upah yang akan diperoleh oleh para pekerja kontrak, maupun keterangan mengenai lokasi dan kondisi di Suriname. Dalam gambar tersebut diinformasikan bahwa letak geografis Suriname adalah $2^{0}-6^{0}$ Lintang Utara, $54^{0}-58^{0}$ Bujur Barat. Temperatur di Suriname adalah $73^{\circ}-87^{\circ} \mathrm{F}$ dan curah hujan antara 60 dan 92 inci. Di dalam gambar tersebut, diinformasikan bahwa di Suriname terdapat ribuan orang pekerja impor/dari luar Suriname sejak 1894. Selain itu diinformasikan pula bahwa pekerjaan yang tersedia di Suriname adalah di perkebunan dan di bidang industri. Mereka juga dijanjikan akan diberikan fasilitas rumah, pengawasan kesehatan dan perlakuan yang baik. Selain itu diinformasikan juga bahwa para pekerja kontrak akan memperoleh upah sebesar empat puluh sen bagi laki-laki, dan tiga puluh sen untuk perempuan per hari dengan bekerja selama tujuh jam sehari. Informasi dalam brosur ini agak sedikit berbeda dengan informasi dari para werk.

${ }^{4}$ Poenale sanctie adalah hak untuk bertindak sebagai polisi dan hakim sekaligus untuk menghukum para kuli tanpa melalui proses pengadilan.

${ }^{5}$ Opseter adalah pegawai yang mengawasi pekerjaan, dalam hal ini pegawai pengawas para pekerja kontrak di perkebunan.

\section{REFERENSI}

Arsip Nasional Republik Indonesia. "Bangsa Indonesia di Suriname Mohon Perhatian Repoeblik", Kedaulatan Rakyat, 13 September 1946.

Arsip Nasional Republik Indonesia. "Kepolisian DIY kepada Kepolisian Negara Bagian PAM (Pengawasan Aliran Masyarakat): surat tentang orang-orang yang pulang dari Suriname" dalam Arsip Kepolisian Negara 1947-1949 No. 720.

Arsip Nasional Republik Indonesia. "Laporan Departemen Keuangan tertanggal 28 Januari 1948” dalam Algemeene Secretarie Templar No. 1031.

Arsip Nasional Republik Indonesia. "Laporan Perjalanan dalam Kapal Tabian oleh Kafiludi tertanggal 27 Oktober 1947” dalam Algemeene Secretarie Templar No. 1031.

Arsip Nasional Republik Indonesia. "Laporan tentang eks pekerja bangsa Indonesia asal Suriname yang diserahkan oleh Belanda, 20 Januari 1948” dalam Arsip Kepolisian Negara 1947-1949 No. 716.

Arsip Nasional Republik Indonesia. "Laporan tentang Warga Negara Indonesia di Suriname” dalam Arsip Kabinet Presiden RI 1950-1959 No. 617.

Arsip Nasional Republik Indonesia. "Mereka jang dari Suriname" dalam Berita ANTARA 8 Desember 1947.

Arsip Nasional Republik Indonesia. "Nota yang dibuat oleh Residen Batavia J.J. Engelberts tertanggal 22 Desember 1947” dalam Algemeene Secretarie Templar No. 1031.

Arsip Nasional Republik Indonesia. "Peraturan Belanda di Suriname Verkate Punale Sanctie? P.B. Parindra minta Perhatian Pemerintah" dalam Berita ANTARA 10 Desember 1954.

Arsip Nasional Republik Indonesia. "Ringkasan tentang Imigran dari Indonesia di Suriname yang dibuat oleh J.J. Engelberts tertanggal 21 Februari 1948" dalam Algemeene Secretarie Templar No. 1031.

Arsip Nasional Republik Indonesia. "Rombongan dari Suriname Menghadap Presiden" dalam Berita ANTARA 13 Desember 1947. 
Arsip Nasional Republik Indonesia. "Surat Direktur Binnenland Bestuur H. van der Wal tertanggal 8 Februari 1947" dalam Algemeene Secretarie Templar No. 1031.

Arsip Nasional Republik Indonesia. "Surat Gubernur Suriname Brons tertanggal 17 Desember 1946" dalam Algemeene Secretarie Templar No. 1031.

Arsip Nasional Republik Indonesia. "Surat Gubernur Suriname Onleesbaar tertanggal 17 Mei 1947" dalam Algemeene Secretarie Templar No. 1031.

Arsip Nasional Republik Indonesia. "Surat Kepala Jawatan Imigrasi kepada Menteri Luar Negeri” tanggal 14 Agustus 1953.

Arsip Nasional Republik Indonesia. "Surat Minister van Overzeese Gebiedsdelen J.M. Kiveron tertanggal 3 Maret 1947" dalam Algemeene Secretarie Templar No. 1031.

Arsip Nasional Republik Indonesia. "Surat Sekretaris Gubernur Suriname tertanggal 22 September 1947” dalam Algemeene Secretarie Templar No. 1031.

Arsip Nasional Republik Indonesia. "Surat Sekretaris Gubernur Suriname tertanggal 9 September 1947" dalam Algemeene Secretarie Templar No. 1031.

Arsip Nasional Republik Indonesia. Harian Umum Nasional, 10 Februari 1954.

Arsip Nasional Republik Indonesia. Imam, Soedjahri, "Transmigrasi Biasa akan Terdjadi bagi 100.000 Djiwa untuk Tahun 1954", Haluan, 9 Februari 1954.

Arsip Nasional Republik Indonesia. Wawancara dengan Antonius Dasimin Senawi pada 3 Desember 2008 (Khasanah Sejarah Lisan ANRI tentang Penelusuran Jejak Masyarakat Suriname di Indonesia).

Arsip Nasional Republik Indonesia. Wawancara dengan Ern Legiman pada 27 Januari 2009 (Khasanah Sejarah Lisan ANRI tentang Penelusuran Jejak Masyarakat Suriname di Indonesia).
Arsip Nasional Republik Indonesia. Wawancara dengan Sastro Amidjan pada 10 Februari 2009 (Khasanah Sejarah Lisan ANRI tentang Penelusuran Jejak Masyarakat Suriname di Indonesia).

Arsip Nasional Republik Indonesia. Wawancara dengan Sentot Durat pada 13 Februari 2009 (Khasanah Sejarah Lisan ANRI tentang Penelusuran Jejak Masyarakat Suriname di Indonesia).

Arsip Nasional Republik Indonesia. Wawancara dengan Stanley S. Kariodimedjo pada 4 Februari 2009 (Khasanah Sejarah Lisan ANRI tentang Penelusuran Jejak Masyarakat Suriname di Indonesia).

Arsip Nasional Republik Indonesia. Wawancara dengan Teguh Paimin Sastroprawiro pada 11 Desember 2008 (Khasanah Sejarah Lisan ANRI tentang Penelusuran Jejak Masyarakat Suriname di Indonesia).

Kuntowijoyo (1995). Pengantar Ilmu Sejarah. Yogya karta: Bentang Budaya.

Kartodirdjo, Sartono (1982). Pemikiran dan Perkembangan Historiografi Indonesia: Suatu Alternatif. Jakarta: Gramedia.

Toon, Fey (2004). Suriname Switi Sranan. Amsterdam: KIT Publisher.

Gottschalk, Louis (1986). Mengerti Sejarah, Terje mahan Nugroho Notosusanto. Jakarta: UI Press.

Hardjo, S.M. (1989). Bunga Rampai Dari Suriname ke Tongar. Jakarta: Balai Pustaka.

Ismael, Yusuf (1955). Indonesia pada Pantai Lautan Atlantik. Djakarta: Perpustakaan Perguruan Kementrian P.P. dan K.

Sarmoedjie (2006). "Mengintip Sejarah Perjuangan Para Mantan Tenaga Kerja Indonesia (TKI) Asal Indonesia di Suriname”. Tidak Diterbitkan. 
